\title{
REVIEW
}

\section{Soccer injury in the lower extremities}

\author{
P Wong, Y Hong
}

Br J Sports Med 2005;39:473-482. doi: 10.1136/bjsm.2004.01551 1

Information about soccer injuries is required to develop prevention and rehabilitation programmes. Most soccer injuries occur in the lower extremities. This type of injury is reviewed here. Definitions of injury, injury rate, injury percentage, mechanism of injury, anatomical region of injury, type of injury, and severity of injury are summarised. In each section, a description and summary of the data are provided. Finally, the limitations of the studies and suggestions to improve the investigation of soccer injuries are provided.

See end of article for authors' affiliations .....................

Correspondence to: Mr Pui-lam Wong, Human Movement Laboratory, Department of Sports Science and Physical Education, The Chinese University of Hong Kong, Hong Kong SAR; delwong@alumni.cuhk.net, delwong@sinatown.com

Accepted 6 February 2005
$\mathrm{S}$ occer is one of the most popular sports throughout the world, with more than 240 million players in 2000. ${ }^{2}$ It is an intermittent sport that uses walking, jogging, running, and sprinting. It involves two teams of 11 players who attempt to propel the ball through a set of goals, while preventing the other team from doing the same. The game consists of two 45 minute halves, with a 15 minute rest between halves.

Previous studies have shown that soccer has a high injury rate and injury percentage. ${ }^{13-12}$ More injuries have been found in soccer than field hockey, volleyball, ${ }^{3}$ handball, basketball, ${ }^{11}$ rugby, cricket, badminton, fencing, cycling, judo, boxing, subaqua, and swimming. ${ }^{13}$ Most soccer injuries occur to the lower extremities, especially the ankle. 5710111415

It has been reported that soccer injuries result in decreased physical activity and work time lost, in addition to substantial medical costs. ${ }^{11} 16$ Eleven review papers that discuss different aspects of soccer injuries have been published. These papers included risk factors, ${ }^{9}{ }^{17} 18$ preventive strategies, ${ }^{1}{ }^{9}$ 19-23 management, ${ }^{21}$ incidence and severity, ${ }^{24}$ as well as evaluation and treatment of injuries. ${ }^{19}$ One of these papers provided a specific review of soccer injuries to the head and neck. ${ }^{25}$ As mentioned, previous studies reported that most soccer injuries were located in the lower extremities. ${ }^{7} 1115$ 26-43 However, no reviews of soccer injuries of this type have been published. This gap needs to be filled to provide information for injury prevention and rehabilitation programmes. Therefore the purpose of this paper is to review articles on soccer injuries to the lower extremities. Information obtained should provide insights and guidelines regarding the design and implementation of prevention and rehabilitation programmes such as proprioceptive training, ${ }^{44}$ education and supervision of coaches and players, ${ }^{45}$ and treatment avoiding reinjury. $^{33}{ }^{46}$ Throughout this paper, the lower extremities include hip, groin, upper leg, knee, lower leg, ankle, and foot.

\section{LITERATURE SEARCH}

A literature search was conducted of the electronic Medline database (the period from 1966 to the 3rd week of February 2004) and SportDiscus (1975 to August 2004). "Soccer injury" and "soccer injuries" were used in the title search. A hand search was also conducted to identify articles not captured in the above searches. Fifty five articles resulted from Medline, 127 from SportDiscus, and eight from the hand search. A total of 132 articles were selected after manual filtration to eliminate duplicate copies and nonEnglish articles. Only the 37 articles that provided data about soccer injuries to the lower extremities were finally selected (table 1 ).

The following sections will discuss the definition of injury, injury rate, injury percentage, mechanism of injury, anatomical region of injury, type of injury, severity of injury, limitations of previous studies, and finally some suggestions for future research.

\section{DEFINITION OF INJURY}

Of the 37 articles selected for this review, three were not included in this section because they did not provide sufficient information about the definition of a reportable injury. In the 34 selected studies, different definitions of injury were used in different studies. One defined injury as any condition that caused a player to be removed from a game, miss a game, or to be disabled enough to come to the medical tent. ${ }^{51}$ Another defined injury as one received during training or competition which prevented the injured player from participating in normal training or competition for more than 48 hours, not including the day of the injury. ${ }^{8}$ Ten studies counted injuries occurring in competition only, whereas 21 counted both competition and training injuries. As shown in table 2, 18 articles further classified injuries into subcategories, but with different classifications. Besides different definitions of injury, different methods were used to collect the data. Eighteen studies used a questionnaire or form to record injury data, three used video records, 21 required a doctor or physiotherapist to examine the injury, and three studies required the authors to check and confirm that it should be classified as an injury.

\section{INJURY RATE}

To avoid confusion in comparing the results among different studies, throughout this paper the definitions of injury rate and injury percentage are separated. Injury rate is defined as the number of injuries per 1000 hours of player 
Table 1 Information on the 37 articles selected for this review paper

\begin{tabular}{|c|c|c|c|c|c|c|}
\hline Year & Study & Population & Sample size & Sex & Period of study (months) & Location \\
\hline 1978 & McMaster $^{47}$ & Professional & 15 & $M$ & 12 & USA \\
\hline 1978 & Nilsson ${ }^{48}$ & Adolescent & 25000 & $F \& M$ & 2987 competitions & International \\
\hline 1980 & Sullivan ${ }^{14}$ & Child \& adolescent & 1272 & $F \& M$ & 12 & USA \\
\hline 1981 & Pritchett $^{16}$ & Adolescent & 10634 & - & 24 & USA \\
\hline 1983 & Ekstrand $^{32}$ & Senior & 180 & $M$ & 12 & Sweden \\
\hline 1985 & Sandelin ${ }^{35}$ & From adolescent to adult & 2072 & $F \& M$ & 12 & Finland \\
\hline 1985 & Schmidt-Olsen ${ }^{34}$ & Adolescent & 6600 & $F \& M$ & 1 & International \\
\hline 1986 & $\mathrm{Hoff}^{42}$ & Adolescent & - & $F \& M$ & - & USA \\
\hline 1989 & Nielsen ${ }^{15}$ & From adolescent to adult & 123 & $M$ & 11 & Denmark \\
\hline 1990 & Ekstrand $^{49}$ & Professional & 639 & $M$ & 12 & Sweden \\
\hline 1990 & Hunt $^{36}$ & From adolescent to adult & - & $F \& M$ & 12 & UK \\
\hline 1990 & $Y d e^{11}$ & Adolescent & 152 & $M$ & 10 & Denmark \\
\hline 1991 & Engstrom $^{50}$ & Professional & 41 & $\mathrm{~F}$ & 12 & Sweden \\
\hline 1993 & Kibler $^{51}$ & Adolescent & - & $F \& M$ & 48 & - \\
\hline 1993 & $\mathrm{NCAA}^{3}$ & Adolescent & - & $F \& M$ & 12 & USA \\
\hline 1994 & $\mathrm{NCAA}^{4}$ & Adolescent & - & $F \& M$ & 12 & USA \\
\hline 1996 & Arnason $^{40}$ & Professional & 84 & $M$ & 5 & Iceland \\
\hline 1996 & Inklaar ${ }^{52}$ & From adolescent to adult & 477 & $M$ & 5 & Netherlands \\
\hline 1996 & Luthje ${ }^{43}$ & Professional & 263 & $M$ & 10 & Finland \\
\hline 1997 & $\mathrm{NCAA}^{53}$ & Adolescent & - & $F \& M$ & 12 & USA \\
\hline 1998 & Hawkins $^{54}$ & Professional & - & $M$ & 36 & UK \\
\hline 1999 & Hawkins ${ }^{7}$ & Professional \& adolescent & - & $M$ & 29 & UK \\
\hline 1999 & Yund $^{39}$ & Child & 1082 & $F \& M$ & 4 & - \\
\hline 2000 & Junge $^{55}$ & Adolescent & 311 & $M$ & 12 & Czech Republic \& Alsace \\
\hline 2000 & Peterson $^{56}$ & From adolescent to adult & 264 & $M$ & 12 & Czech Republic \\
\hline 2001 & Hawkin $^{8}$ & Professional & 2376 & $M$ & 22 & UK \\
\hline 2001 & Morgan $^{29}$ & Professional & 237 & $M$ & 10 & USA \\
\hline 2001 & Soderman ${ }^{26}$ & Adolescent & 153 & $\mathrm{~F}$ & 7 & Sweden \\
\hline 2001 & Steven ${ }^{31}$ & Adolescent & 89500 & $F \& M$ & 120 & USA \\
\hline 2002 & Kirkendall $^{57}$ & Adolescent & 11500 & $F \& M$ & 36 & USA \\
\hline 2002 & Rahnama $^{58}$ & Professional & - & $M$ & 10 competitions & UK \\
\hline 2003 & Giza $^{59}$ & Professional & - & $M$ & 180 competitions & International \\
\hline 2003 & Kakavelakis $^{28}$ & Adolescent & 287 & $M$ & 10 & Greece \\
\hline 2004 & Junge ${ }^{60}$ & Adolescent & 145 & $M$ & 6 & New Zealand \\
\hline 2004 & Junge $^{61}$ & Professional \& adolescent & - & $F \& M$ & 398 competitions & International \\
\hline 2004 & Junge $^{62}$ & Professional & - & $M$ & 64 competitions & International \\
\hline 2004 & Yoon $^{63}$ & Professional \& adolescent & 411 & $M$ & 50 competitions & Asia \\
\hline
\end{tabular}

activity time, or number of injuries per 1000 athleteexposures. Athlete-exposure is one athlete participating in one competition or one training session where he/she is exposed to the possibility of being injured, no matter what amount of time is involved. For example, two competitions involving 40 participants and three training sessions involving 50 participants would result in a total of 230 athleteexposures.

Of the 37 selected articles, 15 were not included in this section because they did not provide sufficient information to calculate an injury rate. Therefore 22 articles were discussed in this section. Only six of them reported injury rate based on 1000 athlete-exposures, whereas 16 reported injury rate based on 1000 hours of activity (table 3). Ten articles provided an overall injury rate as well as that during competition and training, three provided an injury rate during competition and training, and five provided an overall injury rate only.

Most people believe that injury rate during competition is higher than that during training. This is confirmed in fig 1 , which shows that injury rates during competition were always higher than during training, except in one study. This may be because the higher the speed of play, the higher the rate of injury. As the speed and intensity increases, players tend to have more body contact, such as sliding and tackling, which leads to more injury.

Figure 2 shows a comparison of adolescent and professional players from the results of 13 studies. During competition, professional players generally have a higher injury rate than adolescent players. The higher competitive level of professional players usually means that the rewards for winning are greater, and there is more competition for places on a team. This results in more exertion by the players, which may lead to more injuries. However, there seems to be no difference between adolescent and professional players during training (table 3 ).

For the seven studies that included male and female players, we can see a sex difference in injury rate. Injury rate was higher in female players than male players, overall and during training (fig 3). One reason may be that female players are less skilful; with less experience, they may not be able to control the ball as well and avoid injury provoking activities such as tackling and sliding. Peterson $e$ al $^{56}$ reported that players with low skill levels had twice as many injuries as those with higher skill levels (in terms of 1000 hours athlete exposure time). They also suggested that more skilful players might allow them for a reduction in the number of injuries during competition.

On the other hand, male players have higher injury rates than female players during competition. One possible reason is that male players are usually playing at higher competitive levels. The more competitive the match, the greater the speed of movement and more body contact, all of which increase the chances of injury.

\section{INJURY PERCENTAGE}

Injury percentage is defined as the number of injured players divided by total number of players. Seven studies provided injury percentage (table 4). Professional players show a higher injury percentage than adolescent players, possibly for the same reasons as mentioned in the last section. However, injury percentage is less useful than injury rate, because the number of competitions and training sessions varies considerably from one team to another, or even from one year to 
Table 2 Different definitions of injury and methods of data collection in the 34 selected studies

\begin{tabular}{|c|c|c|c|c|c|c|c|c|c|}
\hline Year & Study & Injury classification & $\begin{array}{l}\text { C } \\
\text { only }\end{array}$ & $C \& T$ & $\begin{array}{l}\text { Absence } \\
\mathrm{C} \text { or } \mathrm{T}\end{array}$ & $\begin{array}{l}\text { Check by } \\
\text { doctor \& } \\
\text { PT }\end{array}$ & $\begin{array}{l}\text { Check by } \\
\text { author }\end{array}$ & $\begin{array}{l}\text { Questionnaire/ } \\
\text { form }\end{array}$ & Video \\
\hline 1978 & Nilsson $^{48}$ & - & - & - & - & $\checkmark$ & - & - & - \\
\hline 1978 & McMaster ${ }^{47}$ & - & - & $\checkmark$ & - & - & - & - & - \\
\hline 1980 & Sullivan $^{14}$ & - & - & $\checkmark$ & $\checkmark$ & - & - & - & - \\
\hline 1983 & Ekstrand $^{32}$ & Minor, moderate, major & - & $\checkmark$ & $\checkmark$ & $\checkmark$ & - & - & - \\
\hline 1985 & Schmidt-Olsen ${ }^{34}$ & Slight, moderate, severe & $s$ & - & - & $\checkmark$ & - & - & - \\
\hline 1986 & Hoff $^{42}$ & - & - & $\checkmark$ & $\checkmark$ & - & - & $\checkmark$ & - \\
\hline 1989 & Nielsen $^{15}$ & - & - & $\checkmark$ & $\checkmark$ & $\checkmark$ & - & $\checkmark$ & - \\
\hline 1990 & Ekstrand $^{49}$ & - & - & $\checkmark$ & $\checkmark$ & $\checkmark$ & - & - & - \\
\hline 1990 & $Y_{d e}^{11}$ & $\begin{array}{l}<2 \text { weeks, }>2 \text { weeks, } \\
>4 \text { weeks, }>6 \text { weeks, } \\
>12 \text { weeks }\end{array}$ & - & $\checkmark$ & $\checkmark$ & - & - & - & - \\
\hline 1991 & Engstrom $^{50}$ & Minor, moderate, major & - & $\checkmark$ & $\checkmark$ & $\checkmark$ & $\checkmark$ & - & - \\
\hline 1993 & $N C A A^{3}$ & - & - & $\checkmark$ & $\checkmark$ & - & - & - & - \\
\hline 1993 & Kibler $^{51}$ & - & $\checkmark$ & - & - & - & - & $\checkmark$ & - \\
\hline 1994 & $\mathrm{NCAA}^{4}$ & - & - & $\checkmark$ & $s$ & - & - & - & - \\
\hline 1996 & Arnason $^{40}$ & $\begin{array}{l}<1 \text { week, } 1-2 \text { weeks, } 2- \\
4 \text { weeks, }>4 \text { weeks }\end{array}$ & - & $\checkmark$ & $\checkmark$ & $\checkmark$ & - & - & - \\
\hline 1996 & Inklaar ${ }^{52}$ & - & $\checkmark$ & - & - & $\checkmark$ & $\checkmark$ & $\checkmark$ & - \\
\hline 1996 & Luthje $^{43}$ & Minor, moderate, major & - & $\checkmark$ & - & $\checkmark$ & - & - & - \\
\hline 1997 & $\mathrm{NCAA}^{53}$ & - $\quad$ - n & - & $\checkmark$ & $\checkmark$ & - & - & - & - \\
\hline 1998 & Hawkins $^{54}$ & $\begin{array}{l}\text { Non-injury, minor, } \\
\text { moderate }\end{array}$ & - & - & - & - & - & - & $\checkmark$ \\
\hline 1999 & Hawkins ${ }^{7}$ & $\begin{array}{l}\text { Slight, minor, } \\
\text { moderate, major }\end{array}$ & - & $\checkmark$ & 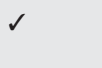 & $\checkmark$ & - & $\checkmark$ & - \\
\hline 1999 & Yund $^{39}$ & - & - & $\checkmark$ & - & $\checkmark$ & - & - & - \\
\hline 2000 & Junge $^{55}$ & Mild, moderate, severe & - & $\checkmark$ & $\checkmark$ & $\checkmark$ & - & $\checkmark$ & - \\
\hline 2000 & Peterson $^{56}$ & Mild, moderate, severe & - & $\checkmark$ & $s$ & $\checkmark$ & - & $\checkmark$ & - \\
\hline 2001 & Soderman ${ }^{26}$ & Minor, moderate, major & - & - & $\checkmark$ & - & $\checkmark$ & $\checkmark$ & - \\
\hline 2001 & Morgan ${ }^{29}$ & Minor, moderate, major & - & $\checkmark$ & $s$ & $\checkmark$ & - & $\checkmark$ & - \\
\hline 2001 & Steven $^{31}$ & - & $d$ & - & - & 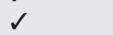 & - & 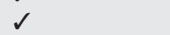 & - \\
\hline 2001 & Hawkin $^{8}$ & $\begin{array}{l}\text { Slight, minor, } \\
\text { moderate, major }\end{array}$ & - & $\checkmark$ & $\checkmark$ & - & - & $\checkmark$ & - \\
\hline 2002 & Kirkendall $^{57}$ & - & $d$ & - & $d$ & - & - & $\checkmark$ & - \\
\hline 2002 & Rahnama $^{58}$ & Minor, moderate, high & 2 & - & - & - & - & - & $d$ \\
\hline 2003 & $\mathrm{Giza}^{59}$ & $\begin{array}{l}\text { Trivial, slight, minor, } \\
\text { moderate, major }\end{array}$ & $s$ & - & $\checkmark$ & $\checkmark$ & - & $\checkmark$ & $\checkmark$ \\
\hline 2003 & Kakavelakis $^{28}$ & Minor, moderate, major & - & $\checkmark$ & 2 & 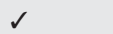 & - & $\checkmark$ & - \\
\hline 2004 & Junge $^{60}$ & $\begin{array}{l}0 \text { day, } 1-7 \text { days, } \\
8-21 \text { days, }>21 \text { days }\end{array}$ & - & $\checkmark$ & $s$ & $\checkmark$ & - & $\checkmark$ & - \\
\hline 2004 & Junge $^{62}$ & - & $\checkmark$ & - & - & $\checkmark$ & - & $\checkmark$ & - \\
\hline 2004 & Junge $^{61}$ & - & $s$ & - & - & $\checkmark$ & - & $\checkmark$ & - \\
\hline 2004 & Yoon $^{63}$ & $\begin{array}{l}0 \text { day, } 1-3 \text { days, } 4-7 \text { days, } \\
8-30 \text { days, }>30 \text { days }\end{array}$ & $s$ & - & $\checkmark$ & $\checkmark$ & - & $\checkmark$ & - \\
\hline
\end{tabular}

another. In addition, not every player participates in every training session and every competition, and the number of participants on a team may change considerably as the season progresses. ${ }^{64}$ Therefore misleading conclusions can be drawn from injury percentage.

\section{MECHANISM OF INJURY}

Five articles provided information about mechanism of injury (table 5). The most common injury mechanisms were tackling, running, being tackled, shooting, twisting and turning, and jumping and landing. Tackling is usually seen in soccer matches when players try to get possession of the ball. The lower extremities are often injured during tackling as players cannot respond quickly enough to avoid such rapid and unpredictable movement. During running and twisting and turning, the main causes of injury are inferior playing surfaces and inappropriate footwear. Uneven playing surfaces may result in more loading on the ligaments and muscles. When external loading is greater than the ligaments and muscles can tolerate, injury usually follows. Incorrect footwear which cannot provide sufficient frictional force will eventually lead to slipping. On the other hand, too much frictional force will produce large torque when twisting and turning, which may also lead to injury. Moreover, defenders will often use any means to prevent opponents from scoring; therefore severe injuries often occur during shooting. In addition, injuries often happen during jumping and landing, which are integral components of activities such as heading, shooting, and goalkeeping. Causes of such injuries are incorrect landing technique and collisions between players after take off and before landing.

Previous studies also show that non-body contact is a primary mechanism of injury. Hawkins and Fuller ${ }^{7}$ reported that injuries caused by non-body contact $(59 \%)$ were more prevalent than injuries caused by body contact $(41 \%)$. In addition, running, shooting, turning, and jumping caused $39 \%$ of all injuries, which were classified as non-body contact. Yde and Nielsen ${ }^{11}$ observed players under 18 years old and reported that $27 \%$ of all injuries were due to running, which is classified as non-body contact injury. Hawkins et $a l^{8}$ observed four professional soccer clubs for two seasons and found that the percentage of non-body contact injuries (58\%) was higher than body contact injuries (38\%). Running (19\%), twisting and turning (8\%), shooting (4\%), and landing (4\%) were the most commonly occurring injury mechanisms, and they were classified as non-contact injury.

\section{ANATOMICAL REGION OF INJURY}

In this review, the lower extremities were divided into the following regions: hip, groin, upper leg, knee, lower leg, 
Table 3 Injury rate data from 22 articles

\begin{tabular}{|c|c|c|c|c|c|c|c|c|}
\hline \multirow[b]{2}{*}{ Year } & \multirow[b]{2}{*}{ Study } & \multirow[b]{2}{*}{ Population } & \multicolumn{3}{|c|}{ Injury rate based on 1000 hours of activity } & \multicolumn{3}{|c|}{ Injury rate based on 1000 athlete-exposures } \\
\hline & & & Overall & Competition & Training & Overall & Competition & Training \\
\hline 1978 & Nilsson $^{48}(M)$ & Adolescent & 23 & - & - & - & - & - \\
\hline 1978 & Nilsson $^{48}$ (F) & Adolescent & 44 & - & - & - & - & - \\
\hline 1980 & Sullivan ${ }^{14}(M)$ & Child \& adolescent & 0.51 & - & - & - & - & - \\
\hline 1980 & Sullivan $^{14}(\mathrm{~F})$ & Child \& adolescent & 1.1 & - & - & - & - & - \\
\hline 1985 & Schmidt-Olsen ${ }^{34}$ (M) & Adolescent & 16.1 & - & - & - & - & - \\
\hline 1985 & Schmidt-Olsen ${ }^{34}$ (F) & Adolescent & 29.9 & - & - & - & - & - \\
\hline 1990 & Ekstrand $^{49}$ & Professional & $9.25^{*}$ & $17.96^{*}$ & $6.2^{*}$ & - & - & - \\
\hline 1990 & Yde" 11 & Adolescent & 5.6 & 9.9 & 1.7 & - & - & - \\
\hline 1991 & Engstrom $^{41}$ & Professional & 12 & 24 & 7 & - & - & - \\
\hline 1993 & $\mathrm{NCAA}^{3}(\mathrm{M})$ & Adolescent & - & - & - & 8.8 & 23.1 & 5.1 \\
\hline 1993 & $\operatorname{NCAA}^{3}(\mathrm{~F})$ & Adolescent & - & - & - & 9.2 & 17.6 & 6.5 \\
\hline 1994 & NCAA $^{4}(M)$ & Adolescent & _- & - & - & 7.6 & 18.7 & 4.6 \\
\hline 1994 & $\mathrm{NCAA}^{4}(\mathrm{~F})$ & Adolescent & - & - & - & 8.6 & 15.5 & 6.4 \\
\hline 1996 & Arnason $^{40}$ & Professional & 12.4 & 34.8 & 5.9 & - & - & - \\
\hline 1996 & Luthje $^{43}$ & Professional & - & 16.6 & 2.1 & - & - & - \\
\hline 1999 & Hawkins ${ }^{7}$ & $\begin{array}{l}\text { Professional \& } \\
\text { adolescent }\end{array}$ & 8.5 & 27.7 & 3.5 & - & - & - \\
\hline 2000 & Junge $^{55}$ (Alsace) & Adolescent & 2.3 & 12.7 & - & - & - & _- \\
\hline 2000 & Junge $^{55}$ (Czech) & Adolescent & 2.6 & 14.8 & - & - & - & - \\
\hline 2000 & Peterson ${ }^{56}$ & $\begin{array}{l}\text { From adolescent } \\
\text { to adult }\end{array}$ & - & 41.7 & 8.8 & - & - & - \\
\hline 2001 & Soderman ${ }^{26}$ & Adolescent & 6.8 & - & - & - & - & - \\
\hline 2001 & Morgan $^{29}$ & Professional & 6.2 & 35.3 & 2.9 & - & - & - \\
\hline 2001 & Steven $^{31}(M)$ & Adolescent & 13.57 & - & - & - & - & - \\
\hline 2001 & Steven ${ }^{31}(\mathrm{~F})$ & Adolescent & 15.38 & - & - & - & - & - \\
\hline 2002 & Kirkendall ${ }^{57}(M)$ & Adolescent & - & - & - & 5.08 & 10.89 & 1.06 \\
\hline 2002 & Kirkendall ${ }^{57}(\mathrm{~F})$ & Adolescent & - & - & - & 4.16 & 9.81 & 54 \\
\hline 2003 & Kakavelakis $^{28}$ & Adolescent & 4 & 5.6 & 3.3 & - & - & - \\
\hline 2004 & Junge $^{60}$ & Adolescent & - & 47.5 & 15.4 & - & - & - \\
\hline 2004 & Junge $^{62}$ & Professional & - & - & - & - & 81 & - \\
\hline 2004 & $\begin{array}{l}\text { Junge }{ }^{61} \text { (World Cup, } \\
\text { 1998) }\end{array}$ & $\begin{array}{l}\text { Professional \& } \\
\text { adolescent }\end{array}$ & - & - & - & - & 72.8 & - \\
\hline 2004 & Junge $^{61}$ (U-20, 1999) & $\begin{array}{l}\text { Professional \& } \\
\text { adolescent }\end{array}$ & - & - & - & - & 108.7 & - \\
\hline 2004 & Junge $^{61}(U-20,2001)$ & $\begin{array}{l}\text { Professional \& } \\
\text { adolescent }\end{array}$ & - & - & - & - & 143.5 & - \\
\hline 2004 & Junge $^{61}$ (U-17, 1999) & $\begin{array}{l}\text { Professional \& } \\
\text { adolescent }\end{array}$ & - & - & - & - & 51.0 & - \\
\hline 2004 & Junge $^{61}(U-17,2001)$ & $\begin{array}{l}\text { Professional \& } \\
\text { adolescent }\end{array}$ & - & - & - & - & 88.1 & - \\
\hline 2004 & $\begin{array}{l}\text { Junge }^{61} \text { (Olympic-Men, } \\
2000)\end{array}$ & $\begin{array}{l}\text { Professional \& } \\
\text { adolescent }\end{array}$ & - & - & - & - & 113.4 & - \\
\hline 2004 & $\begin{array}{l}\text { Junge }{ }^{61} \text { (Confederations } \\
\text { Cup, 1999) }\end{array}$ & $\begin{array}{l}\text { Professional \& } \\
\text { adolescent }\end{array}$ & - & - & - & - & 52.5 & - \\
\hline 2004 & $\begin{array}{l}\text { Junge }{ }^{61} \text { (Confederations } \\
\text { Cup, 2001) }\end{array}$ & $\begin{array}{l}\text { Professional \& } \\
\text { adolescent }\end{array}$ & - & - & - & - & 62.5 & - \\
\hline 2004 & $\begin{array}{l}\text { Junge }{ }^{61} \text { (Club World } \\
\text { Championship, 2000) }\end{array}$ & $\begin{array}{l}\text { Professional \& } \\
\text { adolescent }\end{array}$ & - & - & - & - & 95.7 & - \\
\hline 2004 & $\begin{array}{l}\text { Junge }{ }^{61} \text { (World Cup } \\
\text { Women, 1999) }\end{array}$ & $\begin{array}{l}\text { Professional \& } \\
\text { adolescent }\end{array}$ & - & - & - & - & 38.7 & - \\
\hline 2004 & $\begin{array}{l}\text { Junge }^{61} \text { (Olympic- } \\
\text { Women, 2000) }\end{array}$ & $\begin{array}{l}\text { Professional \& } \\
\text { adolescent }\end{array}$ & - & - & - & - & 64.6 & - \\
\hline 2004 & Junge $^{61}$ (Futsal, 2000) & $\begin{array}{l}\text { Professional \& } \\
\text { adolescent }\end{array}$ & - & - & - & - & 190.9 & - \\
\hline 2004 & Yoon $^{63}$ & $\begin{array}{l}\text { Professional \& } \\
\text { adolescent }\end{array}$ & - & - & - & - & 45.8 & - \\
\hline
\end{tabular}

ankle, and foot. From the 25 selected articles, knee, ankle, upper leg, groin, and hip were the most injured anatomical regions (table 6). Twelve studies provided information on adolescent players only. Of these, 12 reported the ankle, three reported the knee, two reported the upper leg, and two reported the foot as the most commonly injured body parts. A possible reason for the vulnerability of the ankle to injury is its close proximity to the ball, which is the focus of activity in this sport. Therefore the chances of ankle injury are highest when dribbling, shooting, and tackling. Five articles provided information on professional players only, and three reported the upper leg as the most injured body part. The reason for the upper leg being the most injured part for this group may be the large muscle mass and the large area exposed. No conclusions can be drawn for junior and senior football players, as there are limited publications.

There seems to be a difference between male and female players in the body parts most often injured, the former having more ankle injuries and the latter having more knee injuries. The results of the National Collegiate Athletic Association $^{3}$ show that the three most commonly injured body parts for male players were ankle $(20 \%)$, upper leg $(17 \%)$, and knee $(15 \%)$, and those for female players were knee $(24 \%)$, ankle $(21 \%)$, and upper leg (16\%). Lindenfeld and Schmitt ${ }^{65}$ found that the most commonly injured body part of male and female indoor soccer players were the ankle $(23 \%)$ and the knee $(23 \%)$ respectively. Hawkins et a ${ }^{9}$ suggested that the knee is very susceptible to injury from 


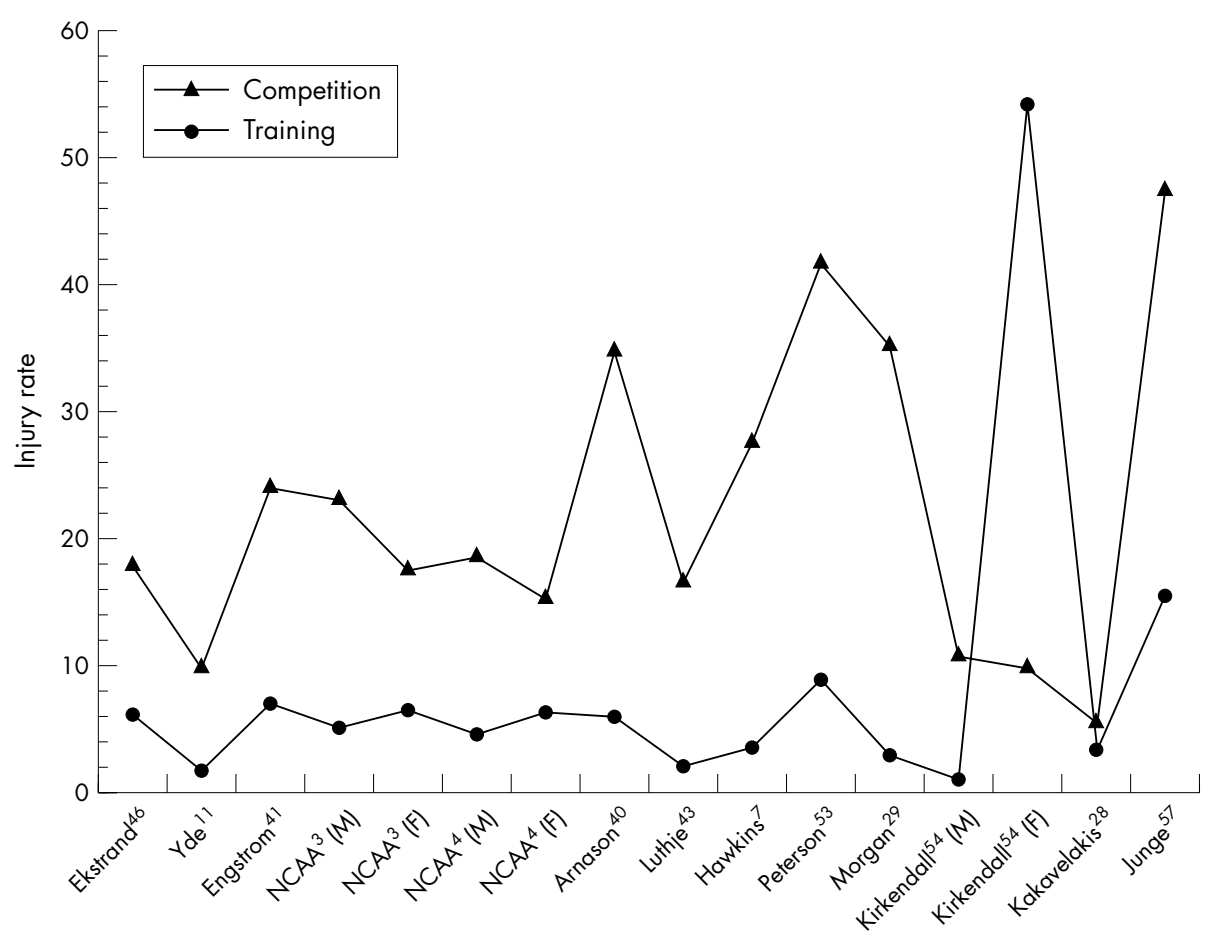

Figure 1 Comparison of football injury rates in competition and training. Data from 13 articles.

large forces produced by kicking the ball. It also is the centre of the lever arm of the leg, so it is susceptible to greater forces being transmitted from the trunk through the hip, and from the ground through the foot and ankle.

\section{TYPE OF INJURY}

In this review, injury types are divided into sprain, strain, contusion, tendinitis (and bursitis), and fracture. Other types of injury are excluded. From the 22 selected articles, sprain, strain, contusion, and tendinitis (and bursitis) were the most common types of injury sustained on the soccer field (table 7). Of these studies, 21 reported contusion, 10 reported sprain, and six reported strain as the most common injury type.

\section{SEVERITY OF INJURY}

In this review, severity of injury was classified according to the number of days absent because of injury. However, others may use different classification systems. For example, SchmidtOlsen $e^{2} a^{34}$ classify severity on the basis of the different treatment used: minor first aid was classified as minor, medical care as moderate, and hospital treatment as major.

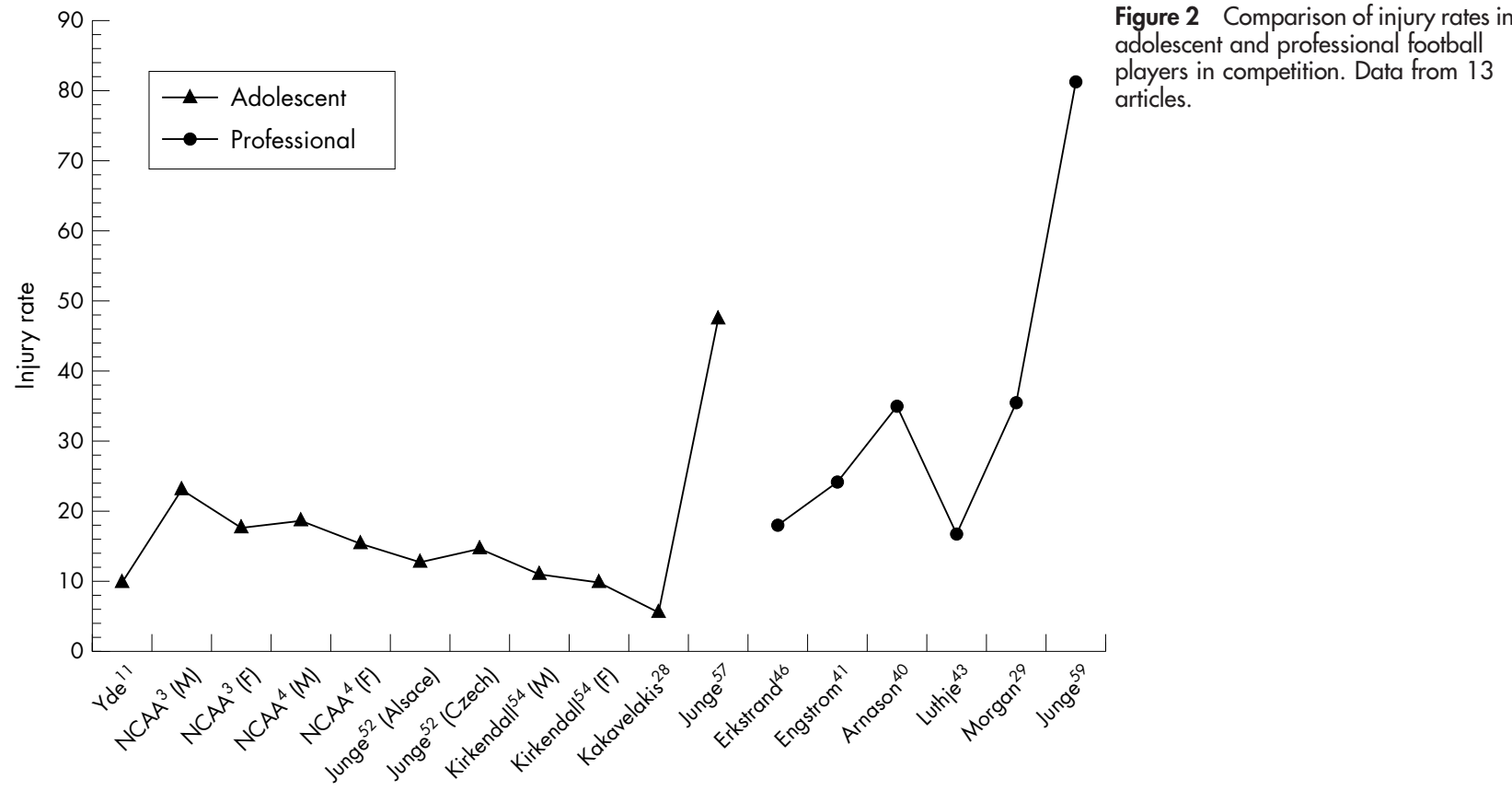




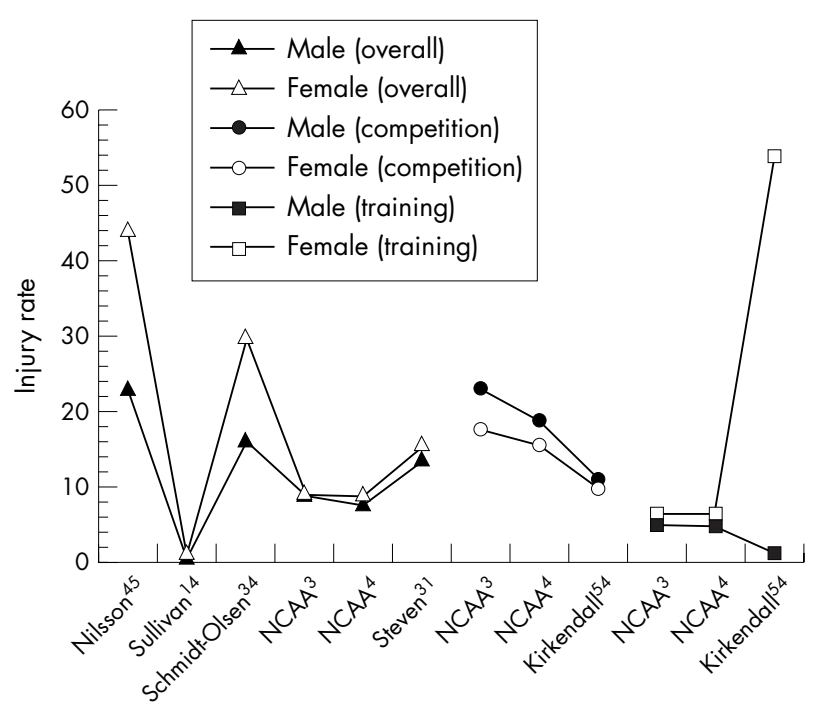

Figure 3 Comparison of injury rates between male and female football players. Data from seven articles.

For those that used number of days absent to classify severity, six classified injury into minor, moderate, and major (table 8). Two of them ${ }^{29}{ }^{32}$ classified minor as absent for less than one week (0-6 days), moderate as absent for more than one week but less than one month (8-29 days), and major as absent for more than one month ( $>30$ days). This system obviously has gaps between classifications where confusion may arise when absence is for one week and one month. Moreover, one $\mathrm{e}^{7}$ did not include injury within the same day ( 0 day), one ${ }^{8}$ did not include injury less than two days (01 day), and one $e^{55}$ did not include injury less than one week (0-6 days). Furthermore, two ${ }^{89}$ had overlapping periods in the classification. Four articles further divided the minor group into slight (one to three days absence) and minor (four to seven days absence). One even had a "trivial" group and one had a "severity 0 " group for injury without absence. The last four articles 26284143 in table 8 classified minor as less than one week (0-6 days), moderate as one week to one month (7-30 days), and major as more than one month ( $>30$ days). This system provides excellent classification of injury severity.

Most soccer injuries tend to be minor, 11 studies showing that most players had minor (including trivial and slight) injury, and three studies showed that most players had moderate injuries. No differences can be observed between adolescent, professional, and senior players.

\section{LIMITATIONS OF PREVIOUS STUDIES}

The data collected by previous studies were by observation during competition, ${ }^{5-7} 1065$ or competition and training. ${ }^{7113249}$
Authors could not control factors that may contribute to the injury, such as type of soccer shoe, intensity of warm up exercise, and condition of the playing surface. Therefore the results from previous studies included all possible factors, which makes it difficult to analyse only one of the factors.

Moreover, different definitions of injury make comparisons between studies difficult. Awareness of the differences in these definitions is important when interpreting the reported results. Some defined injury as one received during competition or training that prevented the injured player from participating in competition or normal training for at least one day, not including the day of the injury, ${ }^{78}$ and another defined injury as any condition that caused a player to be removed from a game, miss a game, or disabled enough to come to the medical tent. ${ }^{51}$

\section{SUGGESTIONS FOR FUTURE RESEARCH}

As mentioned before, different definitions of injury and different methods of data collection were used by different authors. We would like to provide a standardised definition of soccer injury so that comparisons between studies will be easier. We suggest that, in future studies, a reportable soccer injury should be defined as such if it:

(a) occurs in a scheduled competition or training session;

(b) requires medical attention or checking by a professional such as a doctor or physiotherapist;

(c) results in the player being restricted from normal participation for one or more days.

This definition also enables comparison with other sports as it is recommended by other sports such as American football ${ }^{66}$ and 22 sports organised by the National Collegiate Athletic Association. ${ }^{67}$ In addition, information about the injury should be documented and marked clearly, stating if it is new or a recurrence of a previous injury, and if it is from soccer or another sport or is a non-sport injury. This will allow researchers to investigate the difference between soccer injuries and non-soccer injuries, and also allow analysis of data on new and recurring injuries.

Moreover, injury rate per 1000 hours of activity time or 1000 athlete-exposures is preferred, as injury percentage may provide misleading information. Injuries occurring during competition and training should be recorded separately in order to investigate the difference between these two types of participation. However, combining them into a single overall rate is also reasonable if the purpose of study is not to investigate these differences. Furthermore, we suggest classifying injury severity according to the number of days absent because of injury: minor (0-6 days), moderate (730 days), and major (>30 days).

\section{CONCLUSIONS}

Previous studies of soccer injuries defined injury differently. In addition, some studies counted injuries occurring in

\begin{tabular}{llll}
\hline \multicolumn{2}{l}{ Table 4} & Injury percentage from seven articles & \\
\hline Year & Study & Population & $\begin{array}{l}\text { Injury } \\
\text { percentage }\end{array}$ \\
\hline 1980 & Sullivan $^{14}$ & 2.6 \\
1990 & Yde $^{11}$ & Child \& adolescent & $40.68^{*}$ \\
1996 & Luthie $^{43}$ & Adolescent & $64.64^{*}$ \\
2000 & Junge $^{55}$ (Alsace) & Professional & 35.1 \\
2000 & Junge $^{55}$ (Czech) & Adolescent & 50 \\
2000 & Peterson $^{56}$ & Adolescent & $81.82^{*}$ \\
2001 & Soderman $^{26}$ & From adolescent to adult & $36^{*}$ \\
2004 & Junge $^{60}$ & Adolescent & 30.7 \\
\hline \multirow{2}{*}{ *Data in original articles were recalculated to suit the format. } & \\
\hline
\end{tabular}


Table 5 Mechanism of soccer injury taken from five articles

\begin{tabular}{lllllll}
\hline Year & Study & Tackling & Running & $\begin{array}{l}\text { Being } \\
\text { tackled }\end{array}$ & Shooting & $\begin{array}{l}\text { Twisting/ } \\
\text { turning }\end{array}$ \\
\hline 1989 & Nielsen $^{15}$ & 40 & 39 & - & 6 & - \\
1990 & Yde $^{11}$ & 41 & 27 & - & 8 & - \\
1996 & Arnason $^{40}$ & $27.27^{*}$ & $18.18^{*}$ & - & - & - \\
1999 & Hawkins $^{7}$ & 14 & 19 & 23 & $14.29^{*}$ & - \\
2001 & Hawkins $^{8}$ & 9 & 19 & 15 & 4 & $7^{*}$ \\
\hline
\end{tabular}

Values are percentages calculated from total (whole body) injury data.

*Data in original articles were recalculated to suit the format.

Table 6 Anatomical region of injury from 25 articles

\begin{tabular}{|c|c|c|c|c|c|c|c|c|c|}
\hline Year & Study & Population & Hip & Groin & $\begin{array}{l}\text { Upper } \\
\text { leg }\end{array}$ & Knee & $\begin{array}{l}\text { Lower } \\
\text { leg }\end{array}$ & Ankle & Foot \\
\hline 1978 & Nilsson $^{48}$ & Adolescent & - & - & - & 14 & 13 & 16 & 13 \\
\hline 1980 & Sullivan ${ }^{1 / 4}$ & Child \& adolescent & - & - & - & $11.76^{*}$ & - & $41.18^{*}$ & - \\
\hline 1983 & Ekstrand $^{32}$ & Senior & - & 13 & 14 & 20 & 12 & 17 & 12 \\
\hline 1985 & Schmidt-Olsen ${ }^{34}$ (M) & Adolescent & - & - & $15.72^{*}$ & $10.92^{*}$ & $12.23^{*}$ & $12.66^{*}$ & $26.64^{*}$ \\
\hline 1985 & Schmidt-Olsen ${ }^{34}(\mathrm{~F})$ & Adolescent & - & - & $12.82^{*}$ & $8.55^{\star}$ & $5.98^{*}$ & $22.22^{*}$ & $30.77^{\star}$ \\
\hline 1985 & Sandelin ${ }^{35}$ & $\begin{array}{l}\text { From adolescent } \\
\text { to adult }\end{array}$ & $8.64^{*}$ & - & - & $22.20^{*}$ & $6.13^{*}$ & $19.88^{*}$ & $7.05^{*}$ \\
\hline 1989 & Nielsen ${ }^{15}$ & $\begin{array}{l}\text { From adolescent } \\
\text { to adult }\end{array}$ & - & - & - & $18.35^{*}$ & - & $35.80^{*}$ & $8.26^{*}$ \\
\hline 1990 & $Y d e^{11}$ & Adolescent & - & - & - & 19 & - & 27 & 19 \\
\hline 1991 & Engstrom ${ }^{41}$ & Professional & - & 6 & 15 & 23 & 9 & 26 & 9 \\
\hline 1993 & $\mathrm{NCAA}^{3}(\mathrm{M})$ & Adolescent & - & - & 17 & 15 & - & 20 & - \\
\hline 1993 & $\mathrm{NCAA}^{3}(\mathrm{~F})$ & Adolescent & - & - & 16 & 24 & - & 21 & - \\
\hline 1993 & Kibler $^{51}$ & Adolescent & - & - & 21 & 15.8 & - & 13 & 12.8 \\
\hline 1994 & $\operatorname{NCAA}^{4}(M)$ & Adolescent & - & - & 16 & 12 & - & 22 & - \\
\hline 1994 & $\mathrm{NCAA}^{4}(\mathrm{~F})$ & Adolescent & - & - & 19 & 16 & - & 15 & - \\
\hline 1996 & Luthie $^{43}$ & Professional & 2 & - & 22 & 19 & 8 & 17 & 8 \\
\hline 1999 & Hawkins $^{7}$ & $\begin{array}{l}\text { Professional \& } \\
\text { adolescent }\end{array}$ & 3 & 11 & 23 & 14 & 13 & 17 & 6 \\
\hline 2000 & Junge $^{55}$ (Alsace) & Adolescent & - & 5.3 & 14 & 24.6 & 7 & 29.8 & - \\
\hline 2000 & Junge $^{55}$ (Czech) & Adolescent & - & 7.7 & 16.9 & 20.8 & 5.4 & 20.8 & - \\
\hline 2000 & Peterson $^{56}$ & $\begin{array}{l}\text { From adolescent } \\
\text { to adult }\end{array}$ & - & 7.3 & 14.5 & 17.7 & 9.5 & 20.4 & 10 \\
\hline 2001 & Soderman ${ }^{26}$ & Adolescent & $1.27^{*}$ & $5.06^{*}$ & $18.98^{*}$ & $18.98^{*}$ & $12.66^{*}$ & $22.78^{*}$ & $8.86^{*}$ \\
\hline 2001 & Steven $^{31}(M)$ & Adolescent & - & - & $13.55^{*}$ & $15.51^{*}$ & $9.63^{*}$ & $17.91^{*}$ & $8.73^{*}$ \\
\hline 2001 & Steven $^{31}(\mathrm{~F})$ & Adolescent & - & - & $7.80^{*}$ & $19.94^{*}$ & $7.65^{*}$ & $22.66^{*}$ & $6.33^{*}$ \\
\hline 2001 & Morgan $^{29}$ & Professional & - & - & - & 21 & - & 18 & - \\
\hline 2001 & Hawkins $^{8}$ & Professional & 2 & 10 & 23 & 17 & 12 & 17 & 5 \\
\hline 2002 & Kirkendall ${ }^{57}(M)$ & Adolescent & - & - & - & 15.3 & 9.3 & 22 & 6.2 \\
\hline 2002 & Kirkendal $^{57}(\mathrm{~F})$ & Adolescent & - & - & - & 16.3 & 6.95 & 29 & 3.8 \\
\hline 2003 & Kakavelakis $^{28}$ & Adolescent & - & - & 9 & 36 & 6 & 29 & - \\
\hline 2004 & Junge $^{60}$ & Adolescent & 3.2 & 6.1 & 17 & 15 & 16.1 & 17.2 & 5.8 \\
\hline 2004 & Junge $^{62}$ & Professional & $1.17^{*}$ & $5.26^{*}$ & $17.54^{*}$ & $12.87^{*}$ & $16.96^{*}$ & $14.62^{*}$ & $8.19^{*}$ \\
\hline 2004 & $\begin{array}{l}\text { Junge }{ }^{61} \text { (World Cup, } \\
\text { 1998) }\end{array}$ & $\begin{array}{l}\text { Professional \& } \\
\text { adolescent }\end{array}$ & - & - & 20 & 23 & 6 & 13 & - \\
\hline 2004 & Junge $^{61}$ (U-20, 1999) & $\begin{array}{l}\text { Professional \& } \\
\text { adolescent }\end{array}$ & - & - & 22 & 10 & 18 & 15 & - \\
\hline 2004 & Junge $^{61}(U-20,2001)$ & $\begin{array}{l}\text { Professional \& } \\
\text { adolescent }\end{array}$ & - & - & 13 & 12 & 11 & 23 & - \\
\hline 2004 & Junge $^{61}$ (U-17, 1999) & $\begin{array}{l}\text { Professional \& } \\
\text { adolescent }\end{array}$ & - & - & 19 & 9 & 21 & 15 & - \\
\hline 2004 & Junge $^{61}(U-17,2001)$ & $\begin{array}{l}\text { Professional \& } \\
\text { adolescent }\end{array}$ & - & - & 12 & 8.6 & 20 & 16 & - \\
\hline 2004 & $\begin{array}{l}\text { Junge }{ }^{61} \text { (Olympic-Men, } \\
\text { 2000) }\end{array}$ & $\begin{array}{l}\text { Professional \& } \\
\text { adolescent }\end{array}$ & - & - & 14 & 10 & 23 & 12 & - \\
\hline 2004 & $\begin{array}{l}\text { Junge }{ }^{61} \text { (Confederations } \\
\text { Cup, 1999) }\end{array}$ & $\begin{array}{l}\text { Professional \& } \\
\text { adolescent }\end{array}$ & - & - & 8 & 17 & - & - & - \\
\hline 2004 & $\begin{array}{l}\text { Junge }{ }^{61} \text { (Confederations } \\
\text { Cup, 2001) }\end{array}$ & $\begin{array}{l}\text { Professional \& } \\
\text { adolescent }\end{array}$ & - & - & 12 & 15 & 15 & 21 & - \\
\hline 2004 & $\begin{array}{l}\text { Jung e (Club World } \\
\text { Championship, 2000) }\end{array}$ & $\begin{array}{l}\text { Professional \& } \\
\text { adolescent }\end{array}$ & - & - & 17 & 10 & 13 & 17 & - \\
\hline 2004 & $\begin{array}{l}\text { Jung }^{61} \text { e (World Cup } \\
\text { Women, 1999) }\end{array}$ & $\begin{array}{l}\text { Professional \& } \\
\text { adolescent }\end{array}$ & - & - & 8 & 8 & 25 & 17 & - \\
\hline 2004 & $\begin{array}{l}\text { Jung }{ }^{61} \text { e (Olympic-Women, } \\
2000 \text { ) }\end{array}$ & $\begin{array}{l}\text { Professional \& } \\
\text { adolescent }\end{array}$ & - & - & 22 & - & 9 & 22 & - \\
\hline 2004 & Junge $^{61}$ (Futsal, 2000) & $\begin{array}{l}\text { Professional \& } \\
\text { adolescent }\end{array}$ & - & - & 19 & 12 & 17 & 12 & - \\
\hline 2004 & Yoon $^{63}$ & $\begin{array}{l}\text { Professional \& } \\
\text { adolescent }\end{array}$ & 3.6 & 1.2 & 16.7 & 27.4 & 13.1 & 14.3 & 7.1 \\
\hline
\end{tabular}

Values are percentages calculated from total (whole body) injury data. For articles providing data for more than one group of subjects - for example, male and female-results are shown in separate rows.

*Data in original articles were recalculated to suit the format.

NCAA, National Collegiate Athletic Association. 
Table 7 Types of injury from 22 articles

\begin{tabular}{|c|c|c|c|c|c|c|c|}
\hline Year & Study & Population & Sprain & Strain & Contusion & $\begin{array}{l}\text { Tendinitis / } \\
\text { bursitis }\end{array}$ & Fracture \\
\hline 1978 & Nilsso $^{48}$ & Adolescent & - & - & 36 & - & 3.5 \\
\hline 1980 & Sullivan ${ }^{14}$ & Child \& adolescent & $35.29^{*}$ & $8.82^{*}$ & $38.24^{*}$ & - & $5.88^{*}$ \\
\hline 1981 & Pritchett $^{16}$ & Adolescent & - & - & 30.7 & - & 18.8 \\
\hline 1983 & Ekstrand $^{33}$ & Senior & 29 & 18 & 20 & 23 & 4 \\
\hline 1985 & Schmidt-Olsen ${ }^{34}(M)$ & Adolescent & $14.41^{*}$ & $10.48^{*}$ & $33.6^{*}$ & - & - \\
\hline 1985 & Schmidt-Olsen ${ }^{34}$ (F) & Adolescent & $20.51^{*}$ & $8.55^{*}$ & $31.62^{*}$ & - & - \\
\hline 1985 & Sandelin $^{35}$ & $\begin{array}{l}\text { From adolescent } \\
\text { to adult }\end{array}$ & - & - & 34 & - & 7 \\
\hline 1986 & $\mathrm{Hoff}^{42}$ & Adolescent & $34.78^{*}$ & $23.91^{*}$ & $17.39^{*}$ & - & $2.17^{*}$ \\
\hline 1989 & Nielsen ${ }^{15}$ & $\begin{array}{l}\text { From adolescent } \\
\text { to adult }\end{array}$ & $54.35^{*}$ & $21.74^{*}$ & $8.70^{*}$ & $10.87^{*}$ & $4.35^{*}$ \\
\hline 1991 & Engstrom $^{41}$ & Professional & 33 & 10 & 15 & 24 & 1 \\
\hline 1993 & $\mathrm{NCAA}^{3}(\mathrm{M})$ & Adolescent & 26 & 26 & 21 & - & - \\
\hline 1993 & $\mathrm{NCAA}^{3}(\mathrm{~F})$ & Adolescent & 29 & 27 & 11 & - & - \\
\hline 1993 & Kibler $^{51}$ & Adolescent & 21.8 & 24.5 & 32 & - & 9 \\
\hline 1994 & $\mathrm{NCAA}^{4}(\mathrm{M})$ & Adolescent & 27 & 25 & 20 & - & - \\
\hline 1994 & $\mathrm{NCAA}^{4}(\mathrm{~F})$ & Adolescent & 23 & 30 & 17 & - & - \\
\hline 1996 & Arnason $^{40}$ & Professional & $35^{\star}$ & $45^{\star}$ & 20 & - & - \\
\hline 1999 & Hawkins $^{7}$ & $\begin{array}{l}\text { Professional \& } \\
\text { adolescent }\end{array}$ & 2 & 41 & 20 & - & 4 \\
\hline 2000 & Peterson $^{56}$ & $\begin{array}{l}\text { From adolescent } \\
\text { to adult }\end{array}$ & $53.97^{*}$ & $33.03^{*}$ & $4.15^{\star}$ & - & $3.07^{*}$ \\
\hline 2001 & Soderman ${ }^{26}$ & Adolescent & $24.05^{*}$ & $18.99^{*}$ & $8.86^{*}$ & $2.53^{*}$ & $1.27^{*}$ \\
\hline 2001 & Hawkins $^{8}$ & Professional & 19 & 37 & 7 & $5^{*}$ & 4 \\
\hline 2003 & Kakavelakis ${ }^{28}$ & Adolescent & 33 & 23 & 21 & 7 & 8 \\
\hline 2004 & Junge $\mathrm{e}^{60}$ & Adolescent & 20.3 & 31.8 & 28.4 & 3.5 & 1.2 \\
\hline 2004 & Junge $^{62}$ & Professional & $14.04^{*}$ & $14.62^{*}$ & $49.12^{*}$ & $2.92^{*}$ & $1.75^{\star}$ \\
\hline 2004 & Junge $^{61}$ (World Cup, 1998) & $\begin{array}{l}\text { Professional \& } \\
\text { adolescent }\end{array}$ & 12 & 23 & 41 & - & 4 \\
\hline 2004 & Junge $^{61}$ (U-20, 1999) & $\begin{array}{l}\text { Professional \& } \\
\text { adolescent }\end{array}$ & 10 & 5 & 58 & - & 1 \\
\hline 2004 & Junge $^{61}(U-20,2001)$ & $\begin{array}{l}\text { Professional \& } \\
\text { adolescent }\end{array}$ & 5 & 8 & 65 & - & 1.5 \\
\hline 2004 & Junge $^{61}$ (U-17, 1999) & $\begin{array}{l}\text { Professional \& } \\
\text { adolescent }\end{array}$ & 10 & 8 & 76 & - & - \\
\hline 2004 & Junge $^{61}(U-17,2001)$ & $\begin{array}{l}\text { Professional \& } \\
\text { adolescent }\end{array}$ & 13 & 4 & 63 & - & - \\
\hline 2004 & Junge $^{61}$ (Olympic-Men, 2000) & $\begin{array}{l}\text { Professional \& } \\
\text { adolescent }\end{array}$ & 11 & 3 & 65 & - & 1 \\
\hline 2004 & $\begin{array}{l}\text { Junge }{ }^{61} \text { (Confederations } \\
\text { Cup, 1999) }\end{array}$ & $\begin{array}{l}\text { Professional \& } \\
\text { adolescent }\end{array}$ & 20 & 20 & 50 & - & 10 \\
\hline 2004 & $\begin{array}{l}\text { Junge }{ }^{61} \text { (Confederations } \\
\text { Cup, 2001) }\end{array}$ & $\begin{array}{l}\text { Professional \& } \\
\text { adolescent }\end{array}$ & 15 & 15 & 45 & - & 3 \\
\hline 2004 & $\begin{array}{l}\text { Junge }{ }^{61} \text { (Club World } \\
\text { Championship, 2000) }\end{array}$ & $\begin{array}{l}\text { Professional \& } \\
\text { adolescent }\end{array}$ & 17 & 17 & 51 & - & 7 \\
\hline 2004 & $\begin{array}{l}\text { Junge }^{61} \text { (World Cup } \\
\text { Women, 1999) }\end{array}$ & $\begin{array}{l}\text { Professional \& } \\
\text { adolescent }\end{array}$ & 12 & 12 & 35 & - & 8 \\
\hline 2004 & $\begin{array}{l}\text { Junge }^{61} \text { (Olympic-Women, } \\
2000 \text { ) }\end{array}$ & $\begin{array}{l}\text { Professional \& } \\
\text { adolescent }\end{array}$ & 25 & 25 & 44 & - & - \\
\hline 2004 & Junge $^{61}$ (Futsal, 2000) & $\begin{array}{l}\text { Professional \& } \\
\text { adolescent }\end{array}$ & 17 & 17 & 54 & - & 2 \\
\hline 2004 & Yoon $^{63}$ & $\begin{array}{l}\text { Professional \& } \\
\text { adolescent }\end{array}$ & 28.6 & 16.7 & 44 & - & 1.2 \\
\hline \multicolumn{8}{|c|}{$\begin{array}{l}\text { Values are percentages calculated from total (whole body) injury data. For articles providing data for more than one group of subjects - for example, male and } \\
\text { female - results are shown in separate rows. } \\
\text { *Data in original articles were recalculated to suit the format. } \\
\text { NCAA, National Collegiate Athletic Association. }\end{array}$} \\
\hline
\end{tabular}

competition, and some counted both competition and training injuries. They used different classification systems to indicate severity of injury; some classified on the basis of the medical treatment used, and some on the number of days absent because of injury. Different methods were used to collect injury data, such as questionnaire, video records, doctor or physiotherapist examination, and author confirmation. These differences have to be accounted for when comparing different studies.

Injury rate is preferred rather than injury percentage, as injury percentage may provide misleading information. Injury rate (in terms of 1000 hours of activity or 1000 athlete-exposures) during competition is higher than during training. During competition, professional players generally have a higher injury rate (and injury percentage) than adolescent players. However, no differences between professional and adolescent players were observed during training. Female players have a higher injury rate than male players, both overall and during training. However, the reverse is true during competition. Low skill levels and high competitive levels both increase injury rate.

The most common injury mechanisms were found to be tackling, running, being tackled, shooting, twisting and turning, and jumping and landing. Injuries caused by nonbody contact were more prevalent than those caused by body contact. Knee, ankle, upper leg, groin, and hip were the most injured anatomical regions. The knee was the most injured region in adolescent players, whereas the upper leg was the most injured region in professional players. Male players have more ankle injuries, and female players have more knee 


\begin{tabular}{|c|c|c|c|c|c|c|c|}
\hline \multirow[b]{2}{*}{ Year } & \multirow[b]{2}{*}{ Author } & \multirow[b]{2}{*}{ Population } & \multicolumn{5}{|c|}{ Severity classification } \\
\hline & & & $\begin{array}{l}\text { Trivial } \\
\text { (0) }\end{array}$ & $\begin{array}{l}\text { Slight } \\
(1-3)\end{array}$ & $\begin{array}{l}\text { Minor } \\
(4-7)\end{array}$ & $\begin{array}{l}\text { Moderate } \\
(7-30)\end{array}$ & $\begin{array}{l}\text { Major } \\
(>30)\end{array}$ \\
\hline \multirow[t]{2}{*}{2003} & Giza $^{59}$ & Professional & $49.97 \%{ }^{*}$ & $42.42 \%{ }^{*}$ & $3.03 \% *$ & $3.03 \% *$ & $4.55 \%^{*}$ \\
\hline & & & $\begin{array}{l}1 \\
\text { (0) }\end{array}$ & $\begin{array}{l}2 \\
(1-3)\end{array}$ & $\begin{array}{l}3 \\
(4-7)\end{array}$ & $\begin{array}{l}4 \\
(8-30)\end{array}$ & $\begin{array}{l}5 \\
(>30)\end{array}$ \\
\hline \multirow[t]{2}{*}{2004} & Yoon $^{63}$ & Professional \& adolescent & $67.7 \%$ & $22.7 \%$ & $5 \%$ & $3.8 \%$ & $0.8 \%$ \\
\hline & & & & $\begin{array}{l}\text { Slight } \\
(1-3)\end{array}$ & $\begin{array}{l}\text { Minor } \\
(4-6)\end{array}$ & $\begin{array}{l}\text { Moderate } \\
(7-30)\end{array}$ & $\begin{array}{l}\text { Major } \\
(>30)\end{array}$ \\
\hline \multirow[t]{2}{*}{1999} & Hawkins $^{7}$ & Professional \& adolescent & & $16 \%$ & $35 \%$ & $38 \%$ & $11 \%$ \\
\hline & & & & $\begin{array}{l}\text { Slight } \\
(2-3)\end{array}$ & $\begin{array}{l}\text { Minor } \\
(4-7)\end{array}$ & $\begin{array}{l}\text { Moderate } \\
(7-30)\end{array}$ & $\begin{array}{l}\text { Major } \\
(>30)\end{array}$ \\
\hline \multirow[t]{2}{*}{2001} & Hawkins $^{8}$ & Professional & & $10 \%$ & $23 \%$ & $45 \%$ & $23 \%$ \\
\hline & & & & $\begin{array}{l}\text { Slight } \\
\text { (0) }\end{array}$ & $\begin{array}{l}\text { Minor } \\
(1-7)\end{array}$ & $\begin{array}{l}\text { Moderate } \\
(8-21)\end{array}$ & $\begin{array}{l}\text { Major } \\
(>21)\end{array}$ \\
\hline \multirow[t]{2}{*}{2004} & Junge $^{60}$ & Adolescent & & $69.3 \%$ & $19.9 \%$ & $7.3 \%$ & $3.4 \%$ \\
\hline & & & & & $\begin{array}{l}\text { Mild } \\
(7-13)\end{array}$ & $\begin{array}{l}\text { Moderate } \\
(14-30)\end{array}$ & $\begin{array}{l}\text { Severe } \\
(>30)\end{array}$ \\
\hline \multirow[t]{2}{*}{$\begin{array}{l}2000 \\
2000\end{array}$} & $\begin{array}{l}\text { Junge }^{55} \text { (Alsace) } \\
\text { Junge }^{55} \text { (Czech) }\end{array}$ & $\begin{array}{l}\text { Adolescent } \\
\text { Adolescent }\end{array}$ & & & $\begin{array}{l}40.4 \% \\
40 \%\end{array}$ & $\begin{array}{l}31.6 \% \\
35.4 \%\end{array}$ & $\begin{array}{l}28.1 \% \\
24.6 \%\end{array}$ \\
\hline & & & & & $\begin{array}{l}\text { Mild } \\
(0-7)\end{array}$ & $\begin{array}{l}\text { Moderate } \\
(8-29)\end{array}$ & $\begin{array}{l}\text { Severe } \\
(\geqslant 30)\end{array}$ \\
\hline \multirow[t]{2}{*}{2000} & Peterson $^{56}$ & From adolescent to adult & & & $52.15 \%^{*}$ & $32.44 \%^{*}$ & $15.41 \%^{*}$ \\
\hline & & & & & $\begin{array}{l}\text { Minor } \\
(0-6)\end{array}$ & $\begin{array}{l}\text { Moderate } \\
(8-29)\end{array}$ & $\begin{array}{l}\text { Major } \\
(>30)\end{array}$ \\
\hline \multirow[t]{2}{*}{$\begin{array}{l}1983 \\
2001\end{array}$} & $\begin{array}{l}\text { Ekstrand }^{32} \\
\text { Morgan }^{29}\end{array}$ & $\begin{array}{l}\text { Senior } \\
\text { Professional }\end{array}$ & & & $\begin{array}{l}62 \% \\
60 \%\end{array}$ & $\begin{array}{l}27 \% \\
26 \%\end{array}$ & $\begin{array}{l}11 \% \\
14 \%\end{array}$ \\
\hline & & & & & $\begin{array}{l}\text { Minor } \\
(0-6)\end{array}$ & $\begin{array}{l}\text { Moderate } \\
(7-30)\end{array}$ & $\begin{array}{l}\text { Major } \\
(>30)\end{array}$ \\
\hline $\begin{array}{l}1991 \\
1996 \\
2001 \\
2003\end{array}$ & $\begin{array}{l}\text { Engstrom }^{41} \\
\text { Luthie }^{43} \\
\text { Soderman }^{26} \\
\text { Kakavelakis }^{28}\end{array}$ & $\begin{array}{l}\text { Professional } \\
\text { Professional } \\
\text { Adolescent } \\
\text { Adolescent }\end{array}$ & & & $\begin{array}{l}49 \% \\
50 \% \\
34 \% \\
30 \%\end{array}$ & $\begin{array}{l}36 \% \\
36 \% \\
52 \% \\
38 \%\end{array}$ & $\begin{array}{l}15 \% \\
14 \% \\
14 \% \\
32 \%\end{array}$ \\
\hline
\end{tabular}

injuries. Most soccer injuries were contusion, followed by sprain and then strain. Injuries tend to be minor, and no differences in severity between adolescent, professional, and senior players were observed. It is recommended that prevention and rehabilitation programmes should be tailor made and implemented on the basis of these results.

It is suggested that, in future studies, a reportable soccer injury should be defined as injury: $(a)$ occurring in a scheduled competition or training; $(b)$ requiring medical attention or checking by a professional such as a doctor or physiotherapist; and (c) resulting in the player being restricted from normal participation for one or more days.

Information about the injury should be documented and marked clearly stating if it is new or a recurrence of a previous injury, and whether it is from soccer or another sport, or is a non-sport injury. Injury rate per 1000 hours of activity time or 1000 athlete-exposures is preferred. Injuries occurring during competition and training should be recorded separately so that the differences between these two types of participation can be investigated. Severity should be classified according to the number of days absent because of injury: minor (0-6 days); moderate (7-30 days); and major ( $>30$ days $)$.

\section{Authors' affiliations}

P Wong, Y Hong, Human Movement Laboratory, Department of Sports Science and Physical Education, The Chinese University of Hong Kong, Hong Kong SAR

Competing interests: none declared

\section{REFERENCES}

1 Keller CS, Noyes FR, Buncher CR. The medical aspects of soccer injury epidemiology. Am J Sports Med 1987; 15:230-7

2 Football Worldwide 2000: official FIFA survey. FIFA, 2002. http:// images.fifa.com/big_count/BigCount_Players.pdf.

3 Soccer injury rates continue five-year climb. The NCAA News 1993:5.

4 Men's, women's soccer differ in injury-rate patterns. The NCAA News 1994:8.

5 Elias SR. 10-year trend in USA Cup soccer injuries: 1988-1997. Med Sci Sports Exerc 2001;33:359-67.

6 Hawkins RD, Fuller CW. An examination of the frequency and severity of injuries and incidents at three levels of professional football. Br J Sports Med 1998;32:326-32.

7 Hawkins RD, Fuller CW. A prospective epidemiological study of iniuries in four English professional football clubs. Br J Sports Med 1999;33:196-203.

8 Hawkins RD, Hulse MA, Wilkinson C, et al. The association football medical research programme: an audit of injuries in professional football. $\mathrm{Br} J$ Sports Med 2001;35:43-7.

9 McHardy A, Pollard H. Injury associated with soccer: a review of epidemiology and etiology. Journal of Sports Chiropractic and Rehabilitation $2001 ; 15: 34-43$. 
10 Schmidt-Olsen S, Bunemann LKH, Lade $\mathrm{V}$, et al. Soccer injuries of youth. Br J Sports Med 1985;19:161-4.

11 Yde J, Nielsen AB. Sports injuries in adolescents' ball games: soccer, handball and basketball. Br J Sports Med 1990;24:51-4.

12 Rahnama N, Reilly T, Lees A. Injury risk associated with playing actions during competitive soccer. Br J Sports Med 2002;36:354-9.

13 Weightman DL, Browne RC. Injuries in eleven selected sports. J Sports Med 1975;9:136-41.

14 Sullivan JA, Gross RH, Grana WA, et al. Evaluation of injuries in youth soccer. Am J Sports Med 1980;8:325-7.

15 Nielsen $A B, Y d e J$. Epidemiology and traumatology of injuries in soccer. Am J Sports Med 1989;17:803-7.

16 Pritchett JW. Cost of high school soccer injuries. Am J Sports Med 1981:9:64-6.

17 Murphy DF, Connolly DA, Beynnon BD. Risk factors for lower extremity injury: a review of the literature. Br J Sports Med 2003;37:13-29.

18 Keller CS, Noyes FR, Buncher CR. The medical aspects of soccer injury epidemiology. Am J Sports Med 1987;15:230-7.

19 Tucker AM. Common soccer injuries: Diagnosis, treatment and rehabilitation. Sports Med 1997;23:21-32.

20 Inklaar H. Soccer injuries. II. Aetiology and prevention. Sports Med 1994; 18:81-93.

21 Fried T, Lloyd GJ. An overview of common soccer injuries: management and prevention. Sports Med 1992;14:269-75.

22 Engstrom B, Renstrom PA. How can injuries be prevented in the World Cup soccer athlete? Clin Sports Med 1998;17:755-68.

23 Olsen L, Scanlan A, MacKay M, et al. Strategies for prevention of soccer related injuries: a systematic review. Br J Sports Med 2004;38:89-94.

24 Inklaar H. Soccer injuires. I. Incidence and severity. Sports Med 1994; 18:55-73.

25 Tysvaer AT. Head and neck injuries in soccer. Impact of minor trauma. Sports Med 1992;14:200-13.

26 Soderman K, Adolphson J, Lorentzon R, et al. Injuries in adolescent female players in European football: a prospective study over one outdoor soccer season. Scand J Med Sci Sports 2001;11:299-304.

27 Jones SJ, Lyons RA, Sibert J, et al. Changes in sports injuries to children between 1983 and 1998: comparison of case series. J Public Health Med $2001 ; 23: 268-71$

28 Kakavelakis KN, Vlazakis S, Vlahakis I, et al. Soccer injuries in childhood. Scand J Med Sci Sports 2003;13:175-8.

29 Morgan BE, Oberlander MA. An examination of injuries in major league soccer. The inaugural season. Am J Sports Med 2001;29:426-30.

30 Kujala UM, Taimela S, Antti-Poika l, et al. Acute injuries in soccer, ice hockey, volleyball, basketball, judo, and karate: analysis of national registry data. BMJ 1995;311:1465-8.

31 Steven RE. 10-year trend in USA cup soccer injuries: 1988-1997. Med Sci Sports Exerc 2001;33:359-67.

32 Ekstrand J, Gillquist J. Soccer injuries and their mechanisms: a prospective study. Med Sci Sports Exerc 1983;18:267-70.

33 Ekstrand J, Gillquist J. The avoidability of soccer injuries. Int J Sports Med 1983:4:124-8.

34 Schmidt-Olsen S, Bunemann LK, Lade V, et al. Soccer injuries of youth. Br J Sports Med 1985; 19:161-4.

35 Sandelin J, Santavirta S, Kiviluoto O. Acute soccer injuries in Finland in 1980 Br J Sports Med 1985; 19:30-3

36 Hunt $M$, Fulford $S$. Amateur soccer: injuries in relation to field position. Br J Sports Med 1990;24:265.

37 Hennrikus WL, Shaw BA, Gerardi JA, et al. A re-evaluation of injuries in youth soccer. In: American Academy of Pediatrics 1998 Annual Meeting. San Francisco, 1998:785.

38 Yund C, BUckley D, Bianchi D, et al. Longitudinal study of injury rates in 5 to 12-year-old soccer players. Am J Epidemiol 2000;151(suppl):S18.

39 Yund C, Wall E, Specker B. Injury characteristics in 5 to 12 year old soccer players. Med Sci Sports Exerc 1999;31(suppl):S261.

40 Arnason A, Gudmundsson A, Dahl HA, et al. Soccer injuries in Iceland. Scand J Med Sci Sports 1996;6:40-5.
41 Engstrom B, Johansson C, Tornkvist H. Soccer injuries among elite female players. Am J Sports Med 1991;19:372-5.

42 Hoff GL, Martin TA. Outdoor and indoor soccer: injuries among youth players. Am J Sports Med 1986;14:231-3.

43 Luthie P, Nurmi I, Kataja M, et al. Epidemiology and traumatology of injuries in elite soccer: a prospective study in Finland. Scand J Med Sci Sports 1996;6:180-5.

44 Caraffa A, Cerulli G, Projetti M, et al. Prevention of anterior cruciate ligament injuries in soccer. A prospective controlled study of proprioceptive training. Knee Surg Sports Traumatol Arthrosc 1996;4:19-21.

45 Junge A, Rosch D, Peterson L, et al. Prevention of soccer injuries: a prospective intervention study in youth amateur players. Am J Sports Med 2002:30:652-9.

46 Dvorak J, Junge A, Chomiak J, et al. Risk factor analysis for injuries in football players. Possibilities for a prevention program. Am J Sports Med 2000;28(suppl 5):S69-74.

47 McMaster WC, Walter M. Injuries in soccer. Am J Sports Med 1978;6:354-7.

48 Nilsson S, Roaas A. Soccer injuries in adolescents. Am J Sports Med 1978;6:358-61.

49 Ekstrand J, Tropp H. The incidence of ankle sprains in soccer. Foot Ankle 1990;11:41-4.

50 Engstrom B, Forssblad M, Johansson $C$, et al. Does a major knee injury definitely sideline an elite soccer player? Am J Sports Med 1990;18:101-5.

51 Kibler WB. Injuries in adolescent and preadolescent soccer players. Med Sci Sports Exerc 1993;25:1330-2.

52 Inklaar H, Bol E, Schmikli SL, et al. Injuries in male soccer players: team risk analysis. Int J Sports Med 1996;17:229-34.

53 Women's soccer injury rates increase in fall 1996 survey. The NCAA News 1997.

54 Hawkins RD, Fuller CW. An examination of the frequency and severity of injuries and incidents at three levels of professional football. Br J Sports Med 1998;32:326-32.

55 Junge A, Chomiak J, Dvorak J. Incidence of football injuries in youth players: comparison of players from two European regions. Am J Sports Med 2000;28(suppl 5):S47-50.

56 Peterson L, Junge A, Chomiak J, et al. Incidence of football injuries and complaints in different age groups and skill-level groups. Am J Sports Med 2000;28(suppl 5):S51-7.

57 Kirkendall DT, Marchak PM, Garrrett WE. A prospective 3-year injury incidence in youth soccer. Med Sci Sports Exerc 2002;34(suppl):S101.

58 Rahnama N, Reilly T, Lees A. Injury risk associated with playing actions during competitive soccer. Br J Sports Med 2002;36:354-9.

59 Giza E, Fuller C, Junge A, et al. Mechanisms of foot and ankle injuries in soccer. Am J Sports Med 2003;31:550-4.

60 Junge A, Cheung K, Edwards T, et al. Injuries in youth amateur soccer and rugby players: comparison of incidence and characteristics. Br J Sports Med 2004;38: 168-72.

61 Junge A, Dvorak J, Graf-Baumann T, et al. Football injuries during FIFA tournaments and the Olympic games, 1998-2001: development and implementation of an injury-reporting system. Am J Sports Med 2004;32(suppl 1):S80-9

62 Junge A, Dvorak J, Graf-Baumann T. Football injuries during the World Cup 2002. Am J Sports Med 2004;32(suppl 1):S23-7.

63 Yoon YS, Chai M, Shin DW. Football injuries at Asian tournaments. Am J Sports Med 2004;32(suppl 1):S36-42.

64 McKeag DB, Hough DO. Primary care sports med. Madison, WI: Brown \& Benchmark, 1993

65 Lindenfeld TN, Schmitt DJ. Incidence of injury in indoor soccer. Am J Sports Med 1994;22:364-71.

66 Mueller F, Zemper ED, Peters A. American football. In: Caine DJ, Caine CG, Lindner KJ, eds. Epidemiology of sports injuries. Champaign, IL: Human Kinetics Publishers, 1996:41-62.

67 National Collegiate Athletic Association. Injury surveillance system. Washington: NCAA, 2002. 